\title{
腎尿細管性アシドーシス
}

特に血清カルシウムの動態についての一考察

$\begin{array}{ccccc} & \text { 小 } & \text { 出 } & \text { 卓 } & \text { 生 }^{*} \\ \text { 大阪大学医学部泌尿器科学教室 } & \text { 武 } & \text { 本 } & \text { 征 } & \text { 人 } \\ \text { (主任: 園田孝夫教授) } & \text { 板 } & \text { 谷 } & \text { 宏 } & \text { 樹 } \\ & \text { 木 } & \text { 下 } & \text { 勝 } & \text { 博 }\end{array}$

\section{RENAL TUBULAR ACIDOSIS FROM THE ASPECT OF THE KINETICS OF SERUM CALCIUM}

Takuo Koide, Masato Takemoto, Hiroaki Itatani and Katsuhiro Kinoshita

Department of Urology, Osaka University Hospital

(Director: Prof. T. Sonoda, M.D.)

It has been discussed whether parathyroid function on the distal type of renal tubular acidosis (distal RTA) may be activated and result in the negative balance of calcium and inorganic phosphorus.

However, its etiology is obscure.

We reported herein a case of distal RTA that was studied as to serum ionized calcium, inorganic phosphorus and serum parathyroid hormone (PTH) before and after the therapy of the acidosis. The results showed that serum ionized calcium was increased, although total serum calcium was at the lower limit of the normal range and serum PTH level was low $(0.1 \mathrm{ng} / \mathrm{dl})$ in systemic acidosis before the therapy.

After recovery from the acidosis serum ionized calcium was decreased to the normal range with increased total serum calcium and serum PTH (1.2 ng/dl).

Therefore, the parathyroid function on the distal RTA is thought to be mediated by serum ionized calcium.

\section{はじめに}

遠位型腎尿細管性アシドーシスにみられるカルシウム および無機リンの平衡異常の病因に関して副甲状腺機能 亢進症の関与が考觉られているが，いまだに定説はな い。最近我々は，続発性遠位型腎尿細管性アシドーシス の 1 例に扎いて,アシドーシス是正前後の血清イオン化 カルシウム, 血中副甲状腺ホルモン等の推移を観察した 結果, 副甲状腺機能の関与はアシドーシスにより招来さ れた血清イオン化カルシウムの変動を介する二次的なる のであるといら見解を得たのでこれを報告する

\section{症例}

患者：34歳，既婚女子。

初診：昭和48年12月19日。

主訴：口渴, 上肢関節痛叔よび自然排石。
家族歷：特記すべきことなし。

既往歴：特記すべきことなし.

現病歷 : 昭和43年頃から, 口内乾燥, 両煩, 両手掌抒 よび両下肢のしびれ感を自覚し，下肢にしばしば紫斑の 出現を認めたため近医を受診し、リウマチ性紫斑病の診 断にて内科的治療を受けたが改善しなかつた。さらに昭 和45年夏, 小豆大の尿路結石の自然排石を認め某病院を 受診したところ, 両側腎石灰化症を指摘され保存的治療 を受けたが，その後も 1 カ月に 1 個程度の割合で自然排 石が続いた。 他方, 昭和 43 年当時からのしびれ感の増強 に加觉, 肩関節部, 項部抢よび肋骨弓部の疼痛, 顔面色 素沈着招よび反復性の両側耳下腺腫脹等の症状の出現を 認め, 昭和 48 年夏, 某病院内科を受診し膠原病を疑われ た。さらに, 強度の口渴および繰返される自然排石のた め, 昭和 48 年 12 月某病院泌尿器科を受診し, 両側腎石灰 
化症の増強を指摘され，精查のため当科に紹介された．

現症：体格栄養ともに中等度．血圧 112-70 $\mathrm{mm} \mathrm{Hg}$. 脈 拍72/min, 整, 緊張良好. 軽度の顔面色素沈着および雨 側耳下腺部飞軽度の圧痛を認める。胸部理学的所見で は，両側胁骨弓部の軽度圧痛以外飞 異常所見を認めな

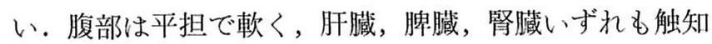
しない，四肢に知覚異常および運動障害のいずれも認め ない。

入院時一般検查成績 : 検尿所見: $\mathrm{pH} 7.0$, 比重 1007 , 蛋白 $( \pm)$, 糖 $(-)$, 赤血球 $(-)$, 白血球 $(H)$, 上皮 (十).血液所見 : 赤血球数 $321 \times 10^{4} / \mathrm{mm}^{3}$, 血色素量 10.5 $\mathrm{g} / \mathrm{dl}$, 白血球数 $5,600 / \mathrm{mm}^{3}$. 血沈值： 1 時間值 $164 \mathrm{~mm}$. 血I 液化学所見 : $\mathrm{Na} 139 \mathrm{mEq} / \mathrm{L}, \mathrm{K} 3.1 \mathrm{mEq} / \mathrm{L}, \mathrm{Cl} 115 \mathrm{mEq} /$ $\mathrm{L}$, 尿素窒素 $20 \mathrm{mg} / \mathrm{dl}$, 総カルシウム $8.8 \mathrm{mg} / \mathrm{dl}$, イオン化カ ルシウム $5.6 \mathrm{mg} / \mathrm{dl}$, 無機リン $3.5 \mathrm{mg} / \mathrm{dl}$, 尿酸 $4.0 \mathrm{mg} / \mathrm{dl}$, クレアチニン $2.1 \mathrm{mg} / \mathrm{dl}$. 尿化学所見 : Na $154 \mathrm{mEq} / \mathrm{day}$, $\mathrm{K} 34 \mathrm{mEq} /$ day, Cl $154 \mathrm{mEq} /$ day 尿素窒素 4,410mg/day, 力

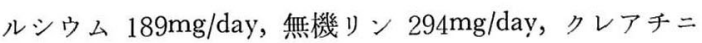
ン $690 \mathrm{mg} / \mathrm{day}, \boldsymbol{ア ミ ノ ~} \mathrm{N}(-)$. 肝機能所見 : 血清総蛋 白量 $9.0 \mathrm{~g} / \mathrm{dl}, \mathrm{A} / \mathrm{G} 0.7$, GPT $10 \mathrm{u}, \mathrm{GOT} 24 \mathrm{u}$. 黄㾝指数 8，アルカリフォスファターゼ 10.0 K.A.u.。止血機能所 見：血小板数 $31.2 \times 10^{4} / \mathrm{mm}^{3}$, PTT $22 \mathrm{sec}$, プロトロンビ ン時間 100\%, 線溶現象 (-). PSP 排泄試験：15分值 $5 \% ， 2$ 時間值 $22 \%$. 動脈血ガス分析所見： $\mathrm{pH} 7.25$, $\mathrm{pO}_{2} 106 \mathrm{mmHg}, \mathrm{pCO}_{2} 28.4 \mathrm{~mm} \mathrm{Hg}$, B.E. $-13.5 \mathrm{mEq} / \mathrm{L},\lceil\mathrm{H}$ $\left.\mathrm{CO}_{3}{ }^{-}\right] 12.2 \mathrm{mEq} / \mathrm{L}$. 血清学的所見 : ASLO $<100 \mathrm{u}, \mathrm{RA}$ $(+)$, CRP (-), LE 細胞現象 (-), 抗核抗体 (-). 血清蛋白電気泳動：アルブミン $48.4 \% ， \alpha_{1}$-グロブリン $1.5 \%, \alpha_{2}$ グロブリン $6.7 \%, \beta$-グロブリン $9.8 \%, \gamma-ク ゙$ ロブリン $33.3 \%$. 免疫グロブリン分画 : IgG $3,880 \mathrm{mg} / \mathrm{dl}$, IgA 492mg/dl, IgM 324mg/dl. 血清渗透圧 : 295mOsm/ $\mathrm{kg} \cdot \mathrm{H}_{2} \mathrm{O}$ ，尿渗透圧： $267 \mathrm{mOsm} / \mathrm{kg} \cdot \mathrm{H}_{2} \mathrm{O}$. 血中副甲状腺 ホルモン: $0.1 \mathrm{ng} / \mathrm{dl}$.

レントゲン学的所見：胸部単純撮影に異常を認めな い. 腎尿管膀胱部単純撮影 で 両側腎石灰化症を認める (Fig，1)，排泄性腎盂撮影では，造影剤排泄の遅延お よび濃縮障害により，腎盂腎杯の描出は不明瞭である。 全身骨単純撮影では異常を認めない, 腫液腺撮影では， 慢性非特異性炎症像を認める。

結石分析所見：リン酸カルシウム結石。

涙液量検查 (Schirmer 法) 所見： 1 分值 $0 \mathrm{~mm}, 5$ 分 值 $1 \mathrm{~mm}$.

以上の所見を要約すると，低カリウム血症および高ク
Fig. 1 : bil. nephrocalcinosis (KUB)

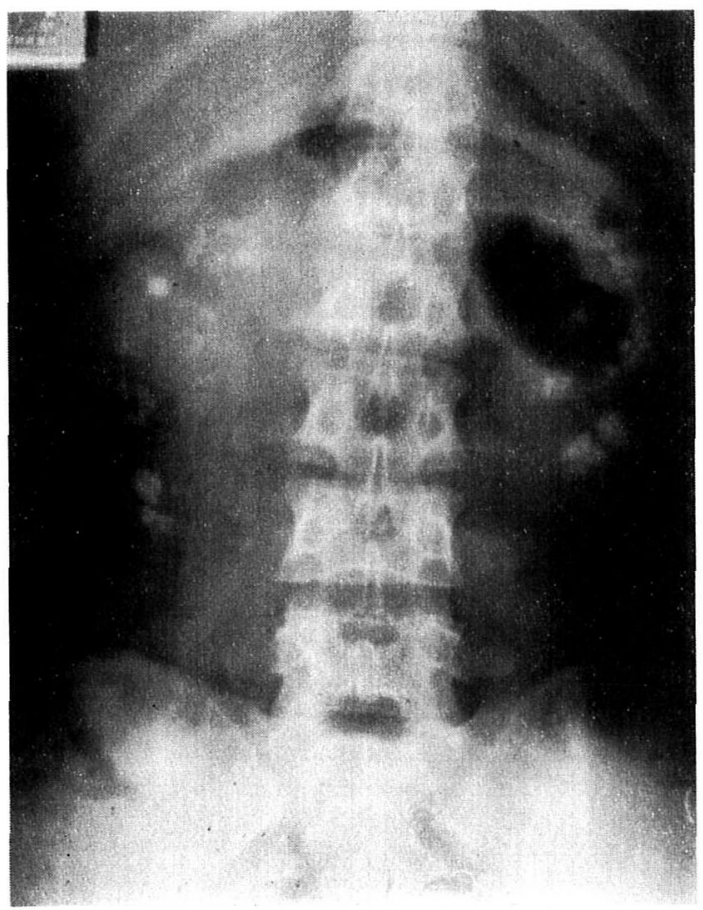

ロール血症を呈する高度の代謝性アシドーシスを認める にも拘らず，尿は常にアルカリ尿を呈し，高度のアシド ーシスのため塩化アンモニウム負荷試験は行い得なから たが，腎尿細管性アシドーシスと診断した。ささら，䧗 床所見扣よび尿 $\mathrm{pH}$ と血清重炭酸イオン濃度の関係から， 重炭酸ナトリウム負荷試験を行うまでもなく，本症例は 遠位型腎原細管性アシドーシスであると判断された。

他方, 口内乾燥, 上肢の関節痛拈よび反復性の両側耳 下腺腫脹等の郜床症状に加总て, 血沈の促進, IgG 増加 を主とする高 $\gamma$ ーグロブリン血症，RA 陽性，沃液量の減 少およびレントゲン学的に認められる睡液腺の炎症像等 の所見は, Sjögren 症候群を疑わせた。

治療: 変法ショール氏液（クエン酸ナトリウム $4.3 \mathrm{~g}$, クエン酸カリウム $5.8 \mathrm{~g}$ ，クエン酸 $14.0 \mathrm{~g}$ ) の投与を行 つた。

入院後経過：Fig 2 亿示す如く, 治療開始後すみやか に代謝性アシドーシスの改善を認め, 同時に血清カリウ ム拉よび無機りンの上昇，血清クロールの低下傾向を認 め, 治療開始後 8 日目には, 血清カリウム $4.2 \mathrm{mEq} / \mathrm{L}$, 血清無機リン $4.0 \mathrm{mg} / \mathrm{dl}$, 血清クロール $103 \mathrm{mEq} / \mathrm{L}$ と正常 域に改善している。ささらに，血清総カルシウムは治療開 
Fig. 2 : clinical course

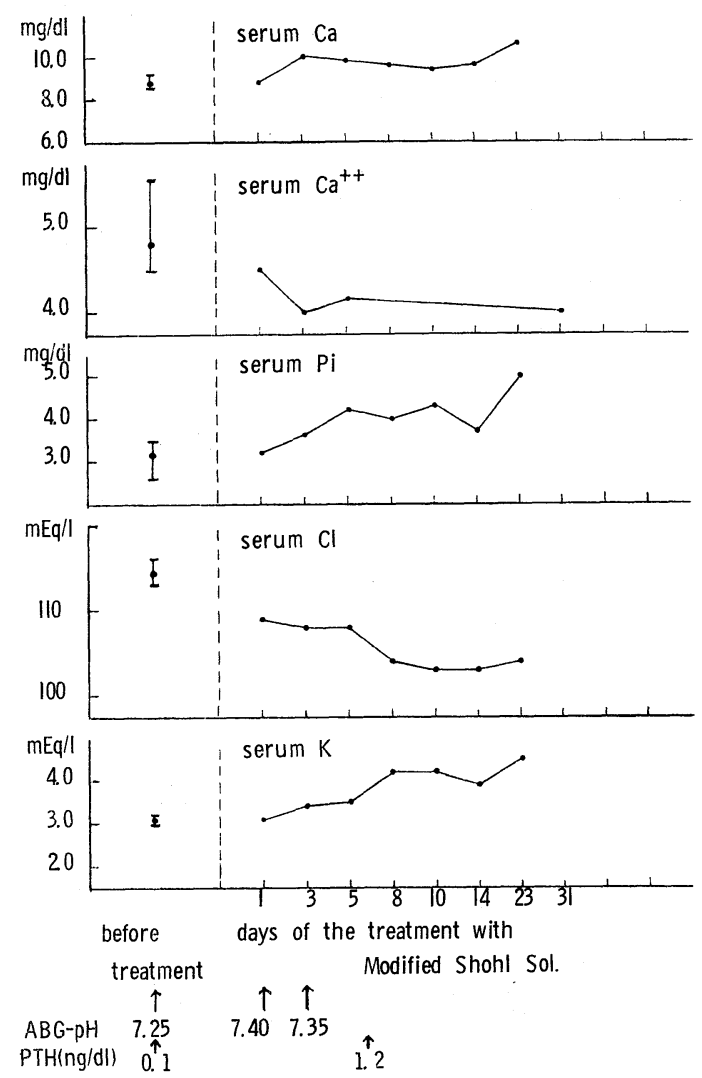

始後に軽度の上昇を示し, 治療開始後 8 日目に $9.4 \mathrm{mg} / \mathrm{dl}$ となつたのに対し，血清イオン化カルシウムは明らかな 低下を示し，治療開始後 8 日目には $4.2 \mathrm{mg} / \mathrm{dl}$ となつてい る。また血中副甲状腺ホルモン值は, 治療前の $0.1 \mathrm{ng} / \mathrm{dl}$ に比して, 治療開始後 6 日目には $1.2 \mathrm{mg} / \mathrm{dl}$ と著明に上 昇している。

その後も血清電解質, 動脈血 $\mathrm{pH}$ 等は, ほぼ正常域に維 持され, 臨床症状に执いて口渴の改善が認められ, 昭和 49 年 2 月 16 日退院し，通院にて治療を継続した。退院後 しばらく自然排石を認めなかつたが，昭和49年 5 月初め から変法ショール氏液の服用を自主的に中断していたと ころ，同 6 月 2 日に左側腹部仙痛発作をきたし，腎尿管 膀胱部単純撮影和よび排泄性腎盂撮影にて, 左尿管総腸 骨動脈交又部に嵌頓せる数個の尿管結石とこれに伴う中 等度の左水腎症を認めたため, 同 6 月 6 日に再入院とな つた. 生化学的検查所見は第 1 回入院時之同様に高度の 代謝性アシドーシスを呈していたため変法ショール氏液
の投与を再び開始すると同時に排石のため保存的治療を 試みたが，結石は不動でさらに数個の結石の尿管への落 下を認め，PSP 排泄試験で15分值 2\%，2 時間值16\%を 示し, 血清尿素窒素 $26 \mathrm{mg} / \mathrm{dl}$ ，血清クレアチニン $3.3 \mathrm{mg} / \mathrm{dl}$ と腎機能低下の傾向を認めたので，同 6 月 21 日左尿管切 石術を施行した。術後 2 週目の点滴静注性腎孟撮影では 左尿管の通過障害は認められず，左水腎症の改善が認め られた。その後数回の自然排石を認めたが同 8 月 3 日軽 快退院した。

\section{考按}

腎尿細管性アシドーシス（以下，RTA と略す）は， 1935年 Lightwood ${ }^{1)}$ 打よび1936年 Butler2) とより初めて 報告されて以来多数の報告を数觉て括り，近年になつて Soriano ら (1969) ${ }^{3)}$ によつて近位型と遠位型に分類さ れ，前者は近位尿細管に和ける重炭酸再吸収閾值の低下 による重炭酸の排泄増加が原因と考兄られ，後者は血液 と遠位尿細管液との間に充分な水素イオン濃度勾配をつ くり得ないことによる水素イオン排泄障害が原因である と報告されている。泌尿器科的には，遠位型 RTA がよ り重要である. 即ち, 遠位型 RTA においてのみ, 低カリ ウム血症，骨病変や腎石灰化症がみられ，近位型 RTA ではこれらの臨床症状を欠如する．従つて臨床的にこの 両者の鑑別は容易であるが，さらに本症例では尿 $\mathrm{pH}$ と血 清重炭酸イオン濃度の関係からも遠位型 RTA であるこ とが確認されだ゙。

他方，本症例ではS Sjögren 症候群を疑わせる高 $\boldsymbol{\gamma}$ グロ ブリン血症を合併しておう，高沢ら (1972） ${ }^{4)}$ の報告に おいても他疾患を合併する遠位型 RTA 16例中11例と高 率に高 $\gamma$ グロブリン血症の合併を認めている。さらに Morris (1969） ${ }^{5)}$ 飞よれば，原発性副甲状腺機能充進 症，高 $\gamma$ グロブリン血症を呈する諸疾患, Medullary Sponge Kidney, 肝硬変, 慢性腎盂腎炎, アンホテリシン Bなどの薬剤，腎移植，諸種遺伝性代謝性疾患など多岐 にわたる先行疾患あるいは原因を認め，これらを続発 性 RTA と定義している.

遠位型 RTA 飞打いて，本症例にみられる如く，腎石 灰化症は腎機能 の低下を招き本疾患の予後を大きく左 右する．従つて本疾患飞打いて，カレシウム拈よび無 機リンの動態が重要であり, 従来より本疾患に和ける カルシウム拉よび無機リンの排泄増加には副甲状腺機 能立進症の関与が唱壳られている。最近でも Wallach ら (1974） ${ }^{6)}$ は原発性遠位型 RTA に続発した副甲状腺 
機能六進症による線維性骨炎の 1 例を報告している。他 方, 遠位型 RTA に通常みられる骨変化は, 副甲状腺機 能充進症に招いて認められる線維性骨炎ではなく骨軟化

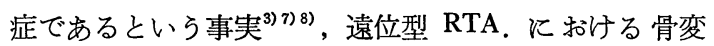

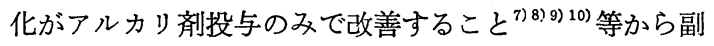
甲状腺機能六進症の関与に対する 疑問も唱えられてい る. .このように, 副甲状腺機能㐫進症の関与の有無に ついては，いまだ混乱の域を脱していないが，本疾患で は，アシドーシスの是正によりカルシウム抌よび無機り ンの平衡は容易に正常化することが広く認められて拉 りまた酸負荷による実験的急性アシドーシスに扔いて 血中副甲状腺ホルモンレベルに有意の变動を認めないこ と など，本疾患に佂けるアシドーシスの一次的な作用 が注目されつつある。

本症例に括いて，アシドーシス是正前後のカルシウム および無機リンの動態および動脈血 $\mathrm{pH}$ ，血中副甲状腺ホ ルモンの変動は興味深いものであつた。即ち, Fig. 2 に示す如く,アシドーシスに执いて血清総カルシウムは 正常下界を示したにも拘らず，血清イオン化カルシウム は明らかな高值を示し，アシドーシスの是正により逆に 血清総カルシウムは軽度の上昇を認め, 血清イオン化カ ルシウムは明らかな低下を認めた。無機リンの動態に関 しても,アシドーシスに拈いて認められた高リン酸尿を 伴う低リン血症はアシドーシスの改善によりすみやかに 正常化した。ささらに血中副甲状腺ホルモンは, アシドー シスでは $0.1 \mathrm{ng} / \mathrm{dl}$ と低值を示したのに対してアシドー シス是正後には $1.2 \mathrm{ng} / \mathrm{dl}$ と明らかな上昇を認めた。

以上の事実ふら，遠位型RTAにおいては，アシドーシ スのため血清イオン化カルシウムは上昇し，むしろ副甲 状腺機能は抑制され，アシドーシス是正による血清イオ ン化カルシウムの低下によつて逆に副甲状腺機能の无進 がもたらされたと考光る。即ち，遠位型 RTA に淤ける 副甲状腺機能の関与は, アシドーシスによつて招来され る血清イオン化カルシウムの変動を介する二次的なるの であると考觉られる。

\section{結語}

34歳女子に発生した著明な腎石灰化症を主訴とする遠 位型 RTA を報告した．本症例に和いて，アシドーシス 是正前後の血清イオン化カルシウム括よび血中副甲状腺 ホルモン測定の結果, 副甲状腺機能の関与は, アシドー シスによつて招来された血清イオン化カルシウムの変動 による二次的なものであると考兄られた．

尚, 血清イオン化カルシウムの測定は Orion 88型 flow-through-electrode Kより行つた.

最後に, 副甲状腺ホルモンの定量を打願いした東大老 年病科 (現, 和歌山医大教授), 藤田拓男博士ならびに, 御校閲を賜りました恩師園田孝夫教授に深謝の意を表し ます。

本論文の要旨は, 第67回日本泌尿器科学会関西地方会 において発表した。

\section{文献}

1) Lightwood, R.: Arch. Dis. Childh., 10, 205, 1935.

2) Butler, A.M., Wilson, J.L. and Farber, S.: J. Pediat., 8, 489, 1936.

3) Soriano, J.R. and Edelmann, C.M.: Ann. Rev. Med., 20, 363, 1969.

4) 高沢靖紀, 岡崎 隆, 木下真男, 里吉営二郎 : 日内会誌，61，69，1972.

5) Morris, R.C.: New Engl. J. Med., 281, 1405, 1969.

6) Wallach, S., Baker, R.K. and Nicastri, A.: Amer. J. Med., 52, 809, 1974.

7) Pines, K.L. and Mudge, G.H.: Amer. J. Med., 11, 302, 1951.

8) Richards, P., Chamberlain, M.J. and Wrong, O.M.: Lancet, 2, 994, 1972.

9) Foss, G.L., Perry, C.B. and Wood, F.J.Y.: Quart. J. Med., 25, 185, 1956.

10) Dent, C.E.: J. Bone Jt. Surg., 34B, 266, 1952.

11) Kaplan, E.L., Peskin, G.W. and Jaffe, B.M.: Surgery, 72, 53, 1972.

（1975 年 6 月 27 日 受付） 